\title{
High Strain Rate and/or Low Temperature Superplasticity in AZ31 Mg Alloys Processed by Simple High-Ratio Extrusion Methods
}

\author{
H. K. Lin and J. C. Huang \\ Institute of Materials Science and Engineering, National Sun Yat-Sen University, Kaohsiung, Taiwan 804, R. O. China
}

\begin{abstract}
There have been numerous efforts in processing metallic alloys into fine-grained materials, so as to exhibit high strain rate superplasticity (HSRSP) and/or low temperature superplasticity (LTSP). The current study applied the most simple and feasible one-step extrusion method on the commercial AZ31 magnesium ingot to result in HSR\&LTSP. The one-step extrusion was undertaken using a high extrusion ratio at $250-350^{\circ} \mathrm{C}$, and the grain size after one-step extrusion became $\sim 1-4 \mu \mathrm{m}$. The processed AZ31 plate exhibited satisfactory room temperature tensile elongation of $30-50 \% ; 200^{\circ} \mathrm{C}$ elongations of $600 \%$ at $1 \times 10^{-4} \mathrm{~s}^{-1}$ and $425 \%$ at $1 \times 10^{-3} \mathrm{~s}^{-1}$; and $300^{\circ} \mathrm{C}$ elongations of $900 \%$ at $1 \times 10^{-4} \mathrm{~s}^{-1}, 520 \%$ at $8 \times 10^{-3} \mathrm{~s}^{-1}, 300 \%$ at $2 \times 10^{-2} \mathrm{~s}^{-1}$, and $210 \%$ at $1 \times 10^{-1} \mathrm{~s}^{-1}$. This suggests that the current AZ31 Mg alloy has possessed HSRSP at relatively low temperatures of $280-300^{\circ} \mathrm{C}$, as well as LTSP at $200^{\circ} \mathrm{C}$. The low flow stress of $15-30 \mathrm{MPa}$ and the true strain rate sensitivity of $0.3-0.4$ both suggest that grain boundary sliding and solute drag creep have operated under these loading conditions. The current results imply that the simple high-ratio extrusion method might be a feasible processing mean for industry applications.
\end{abstract}

(Received April 12, 2002; Accepted August 7, 2002)

Keywords: magnesium alloy, high strain rate superplasticity, low temperature superplasticity, extrusion, texture

\section{Introduction}

There have been numerous efforts in processing metallic alloys into fine-grained materials, so as to exhibit high strain rate superplasticity (HSRSP) and/or low temperature superplasticity (LTSP). The processing means include thermomechanical treatments (TMT), equal channel angular pressing (ECAP), multiple forging, cyclic extrusion, high-ratio extrusion, torsion under compression, accumulative roll-bonding (ARB), rapid solidification, powder metallurgy, or electrodeposition, etc.

Over the past few years, the development of fine-grained $\mathrm{Mg}$ base alloys so as to exhibit superplastic capability has been gradually emerged. The $\mathrm{AZ}$ and $\mathrm{ZK}$ series $\mathrm{Mg}$ alloys appeared to be among the most popular candidates. ${ }^{1-14)}$ Table 1 summarizes the reported superplastic performance of these alloys. Tensile elongations higher than $1000 \%$ have been observed in numerous cases. For example, the rapid solidified AZ91 $100 \mu \mathrm{m}$ ribbons after folding and extrusion, resulting in a fine grain size of $1.2 \mu \mathrm{m}$, were reported to exhibit an elongation over $1000 \% .{ }^{4)}$ Compatible results were found in the AZ91D alloy after reciprocal extrusion $\left(1000 \%\right.$ at $300^{\circ} \mathrm{C}$ and $\left.1 \times 10^{-3} \mathrm{~s}^{-1}\right),{ }^{13}$ or after high-ratio one-step extrusion $(1200 \%$ at $300^{\circ} \mathrm{C}$ and $\left.1 \times 10^{-3} \mathrm{~s}^{-1}\right){ }^{14)}$ The high superplastic elongation of $1000 \%$ has also been reported for expensive $\mathrm{Mg}-$ $4 \mathrm{Y}-3 \mathrm{RE}-0.5 \mathrm{Zr}(\mathrm{WE} 43)$ at $400^{\circ} \mathrm{C} .{ }^{15)}$ The supreme superplastic behavior of the commercial $\mathrm{Mg}$ alloys can be applied in the press forming ${ }^{16)}$ or press forging process for making Mg enclosures for electromagnetic shielding purpose concerned in the $3 \mathrm{C}$ (computer, communication and consumer electronic) industry.

By proper control of the thermomechanical treatment, the $\mathrm{Mg}$ alloys can be processed into uniform fine grains measuring within $2-20 \mu \mathrm{m}$, depending on the processing deformation amount and following heat treatments. The lattice and grain boundary diffusion rates of the $\mathrm{Mg}$ base alloys are around $3 \times$ and $18 \times$ faster, respectively, than those of the $\mathrm{Al}$ base alloys at the typical processing and heat treatment temperature of $\sim 300^{\circ} \mathrm{C} .{ }^{17)}$ Due to the relatively faster diffusion rate, the $\mathrm{Mg}$ alloys tend to possess better defined equiaxed fine grains that favorable for grain boundary sliding during the subsequent tensile loading at elevated temperatures. Since the previous processing means, such as ECAP, multiple reciprocal extrusion or rapid solidification plus extrusion, usually produce smaller or rod-shaped products, the current study applied the most simple and feasible one-step plate-extrusion methods on the popular and low-priced commercial AZ31B magnesium alloy, to result in superior high strain rate and/or low temperature superplasticity.

Previous efforts in using high-ratio extrusion to refine the grain size in $\mathrm{Mg}$ base alloys and composites have been conducted by Higashi and co-workers. ${ }^{18-20)}$ The extrusion ratio applied was mostly $44: 1$ or $100: 1$. In this study, the extrusion ratio will be further increased to be greater than 150:1, so as to achieve a processing strain compatible to those experienced during ECAP. Although high strain rate superplasticity has been observed in many Al base alloys and composites e.g. ${ }^{21)}$ or $\mathrm{Mg}$ composites e.g., ${ }^{22,23)}$ there have been very limited results on the $\mathrm{Mg}$ alloys. Wu et al. ${ }^{24,25)}$ reported a superplastic-like elongation of $189-250 \%$ in the AZ31 alloy tested at $500^{\circ} \mathrm{C}$ and $1 \times 10^{-2} \mathrm{~s}^{-1}$; and Mukai et al. ${ }^{26)}$ achieved $\sim 180 \%$ elongation for the extruded AZ31 as tested at $350^{\circ} \mathrm{C}$ and $1 \times 10^{-2} \mathrm{~s}^{-1}$. It would be desirable to explore whether the alloy can exhibit HSRSP over 200\% at even lower temperatures. The current study will aim on the development of HSRSP and/or LTSP in the AZ31 alloy through the simple high-ratio extrusion method.

\section{Experimental Methods}

The AZ31B alloys used in this study were purchased from CDN Company, Canada. The chemical composition in mass percent is $\mathrm{Mg}-3.02 \% \mathrm{Al}-1.01 \% \mathrm{Zn}-0.30 \% \mathrm{Mn}$ (plus $0.007 \% \mathrm{Si}, 0.003 \% \mathrm{Cu}$ and $0.003 \% \mathrm{Fe}$ ). The as-received al- 
Table 1 Summary of the low temperature superplastic performance in commercial AZ and ZK series Mg alloys.

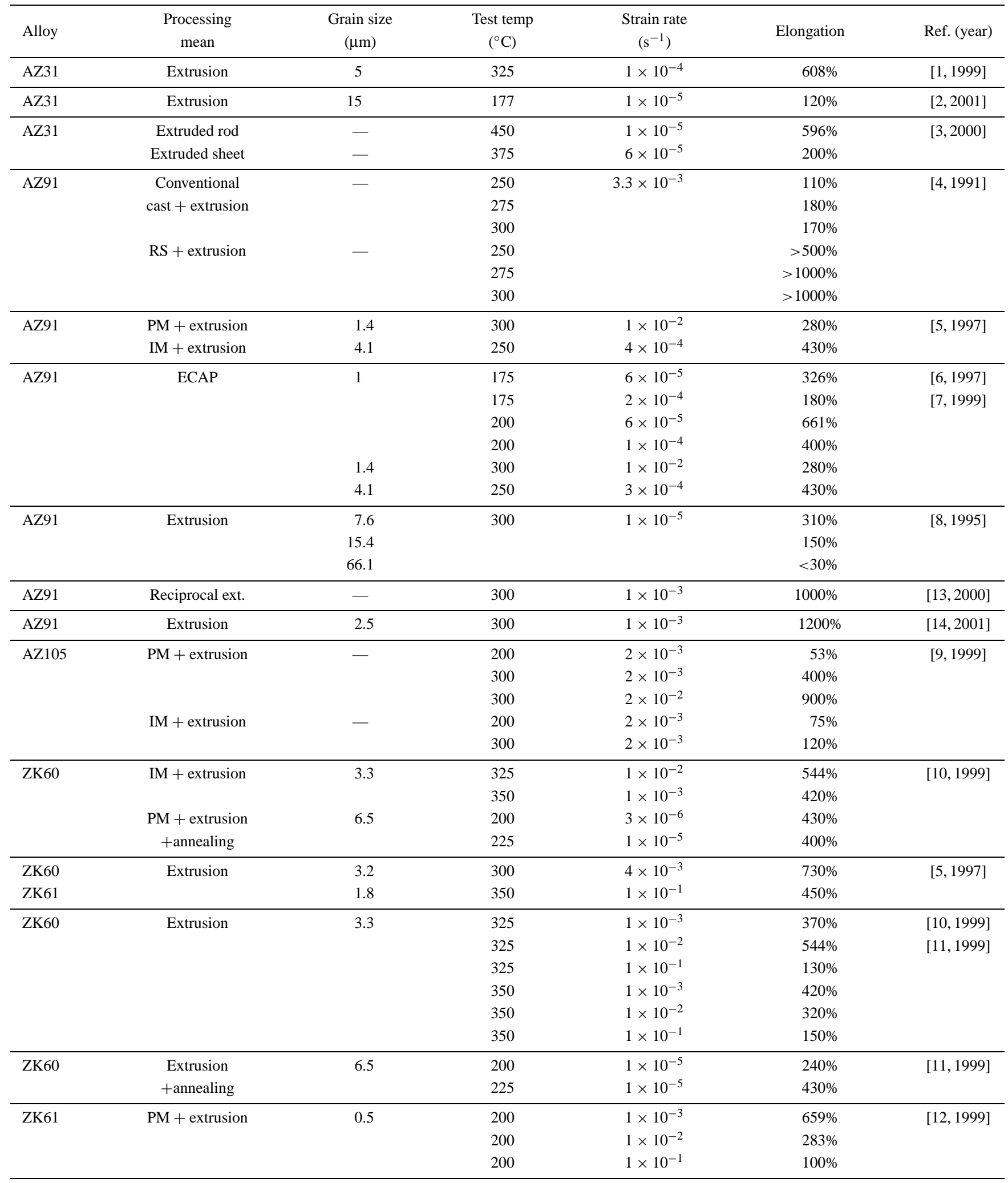

loy was fabricated through semi-continuous casting and has the form of extruded billet measuring $178 \mathrm{~mm}$ in diameter and $300 \mathrm{~mm}$ in length. The extruded billet possessed nearly equiaxed grains around $70 \mu \mathrm{m}$. Upon subject to tensile tests, the as-received billet exhibited tensile elongations less than $150 \%$ over the range of $25-350^{\circ} \mathrm{C}$ and $10^{-4}-10^{-1} \mathrm{~s}^{-1}$, and did not reveal any HSRSP or LTSP property.
The one-step extrusion was undertaken using a high extrusion ratio at $250-350^{\circ} \mathrm{C}$. The initial input rod-shaped sample for laboratory uses, with a diameter of $65 \mathrm{~mm}$, was extruded into a plate-shaped product with a plate width of $10-65 \mathrm{~mm}$ and plate thickness of $1-2 \mathrm{~mm}$, resulting in extrusion ratios from 25-166 (or a true extrusion strain of 3.2-5.1). Parallel experiments on the AZ91D alloys also showed that the one- 
step extrusion could be replaced by two-step extrusion with the same total accumulated strain, ${ }^{14)}$ and slightly degraded but still compatible superplastic results could also be achieved. It was found that a high extrusion ratio would result in finer grain structures and superior HSRSP and/or LTSP characteristics. In what follows, most tensile results were obtained from specimens extruded to $2 \mathrm{~mm}$ thick using the highest ratio of 166:1, except where indicated.

Constant crosshead speed tensile tests were conducted using an Instron 5582 universal testing machine equipped with a three-zone furnace, with the loading direction parallel to the extrusion direction. The temperature was controlled within $\pm 2^{\circ} \mathrm{C}$. It usually took $50 \mathrm{~min}$ for the tested specimens to reach the desired loading temperature without thermal fluctuations. Different heating rates were tried, and 50 min seemed to be optimum in terms of LTSP elongation performance and instrument stability. The specimen gauge length and width were 8 and $3 \mathrm{~mm}$, respectively, with a shoulder radius of curvature of $2 \mathrm{~mm}$.

In order to examine the stability of the grain size during static annealing and dynamic loading, the specimens extruded by a high extrusion ratio were further heated to 150, 200, 250, 300 and $350^{\circ} \mathrm{C}$ and held for $0-10 \mathrm{~h}$, followed by tensile loading under various loading conditions. The microstructures and post-annealing superplastic properties were characterized and compared. The grain structures of the etched specimens were revealed by optical microscopy (OM) or scanning electron microscopy (SEM). The crystalline orientations of the asextruded as well as the annealed specimens were examined by $\mathrm{X}$-ray diffraction. For the rod ingot billet, the cross-sectional plane was placed to receive the incident $\mathrm{Cu} \mathrm{K} \alpha \mathrm{X}$-ray. In contrast, the plane facing to the $\mathrm{X}$-ray for the extruded plate was the flat extrusion surface.

\section{Results and Discussion}

\subsection{Grain size}

The grain size of the AZ31 alloy after one-step high-ratio extrusion was significantly reduced from the original $70 \mu \mathrm{m}$. It became $\sim 9,4.5$, and $2.5 \mu \mathrm{m}$ after extrusion to $42: 1,100: 1$ and 166:1. The nearly equiaxed grain structure in $2 \mathrm{~mm} \mathrm{spec-}$ imens subjected to 166:1 extrusion is shown in Fig. 1(a). After static annealing at $150-300^{\circ} \mathrm{C}$ for $1 \mathrm{~h}$, the grain boundaries appeared to be well defined as shown in Fig. 1(b), and the grain size in the $166: 1$ specimen increased slightly to 2.6 to $2.8 \mu \mathrm{m}$ (Table 2), suggesting that the grain size was fairly stable upon exposure at temperatures below $300^{\circ} \mathrm{C}$. The grain sizes of the extruded specimens after static annealing at $300^{\circ} \mathrm{C}$ for 1 to $10 \mathrm{~h}$ were seen to increase from 2.8 to $3.9 \mu \mathrm{m}$, as listed in Table 2. This implies that the grain structure in the heavily extruded AZ31 alloy can remain its fine grains at $T \leq 300^{\circ} \mathrm{C}$ for a long period of loading or forming time. However, at an even higher temperature of $350^{\circ} \mathrm{C}$ for 1 or $10 \mathrm{~h}$, the grains grew appreciably to 5.2 or $6.5 \mu \mathrm{m}$.

During tensile loading over $25-300^{\circ} \mathrm{C}$, the grain size remained highly stable. For the 100:1 specimens, the grain size of the as-extruded alloy $(4.5 \mu \mathrm{m})$ was further refined to 3 and $4 \mu \mathrm{m}$ when tensile loaded at 250 and $300^{\circ} \mathrm{C}$ at a strain rate of $1 \times 10^{-3} \mathrm{~s}^{-1}$. And the $2.5 \mu \mathrm{m}$ grain size in the $166: 1$ specimens was also consistently refined to $\sim 2 \mu \mathrm{m}$ as tensile loaded
Table 2 Summary of the measured grain size and X-ray peak intensity ratio for the (0002) reflection over the (1011) and (1013) reflections in the AZ31 alloy extruded to $166: 1$ into a plate of $2 \mathrm{~mm}$ thick.

\begin{tabular}{lccc}
\hline \multicolumn{1}{c}{ Material condition } & $\begin{array}{c}\text { Grain size } \\
(\mu \mathrm{m})\end{array}$ & $I_{(0002)} / I_{(10 \overline{1} 1)}$ & $I_{(0002)} / I_{(10 \overline{1})}$ \\
\hline As-received ingot & 70 & 0.6 & 5 \\
As-extruded plate & 2.5 & 14.6 & 19 \\
Post-annealed at $150^{\circ} \mathrm{C}$ for $1 \mathrm{~h}$ & 2.6 & 23.0 & 23.0 \\
Post-annealed at $150^{\circ} \mathrm{C}$ for $10 \mathrm{~h}$ & - & 60.0 & 40.0 \\
Post-annealed at $200^{\circ} \mathrm{C}$ for $1 \mathrm{~h}$ & 2.7 & - & - \\
Post-annealed at $200^{\circ} \mathrm{C}$ for $10 \mathrm{~h}$ & - & - & - \\
Post-annealed at $250^{\circ} \mathrm{C}$ for $1 \mathrm{~h}$ & 2.8 & 22.0 & 14.7 \\
Post-annealed at $250^{\circ} \mathrm{C}$ for $10 \mathrm{~h}$ & - & 10.7 & 14.7 \\
Post-annealed at $300^{\circ} \mathrm{C}$ for $1 \mathrm{~h}$ & 2.8 & 23.0 & 13.5 \\
Post-annealed at $300^{\circ} \mathrm{C}$ for $3 \mathrm{~h}$ & 2.9 & - & - \\
Post-annealed at $300^{\circ} \mathrm{C}$ for $5 \mathrm{~h}$ & 3.7 & 12.4 & 6.8 \\
Post-annealed at $300^{\circ} \mathrm{C}$ for $10 \mathrm{~h}$ & 3.9 & 10.8 & 5.4 \\
Post-annealed at $350^{\circ} \mathrm{C}$ for $1 \mathrm{~h}$ & 5.2 & 7.5 & 3.6 \\
Post-annealed at $350^{\circ} \mathrm{C}$ for $10 \mathrm{~h}$ & 6.5 & 7.5 & 4.0 \\
Tensile loaded at $200-300^{\circ} \mathrm{C}$ & 2.0 & - & - \\
and $1 \times 10^{-3} \mathrm{~s}{ }^{-1}$ & & & \\
\hline
\end{tabular}
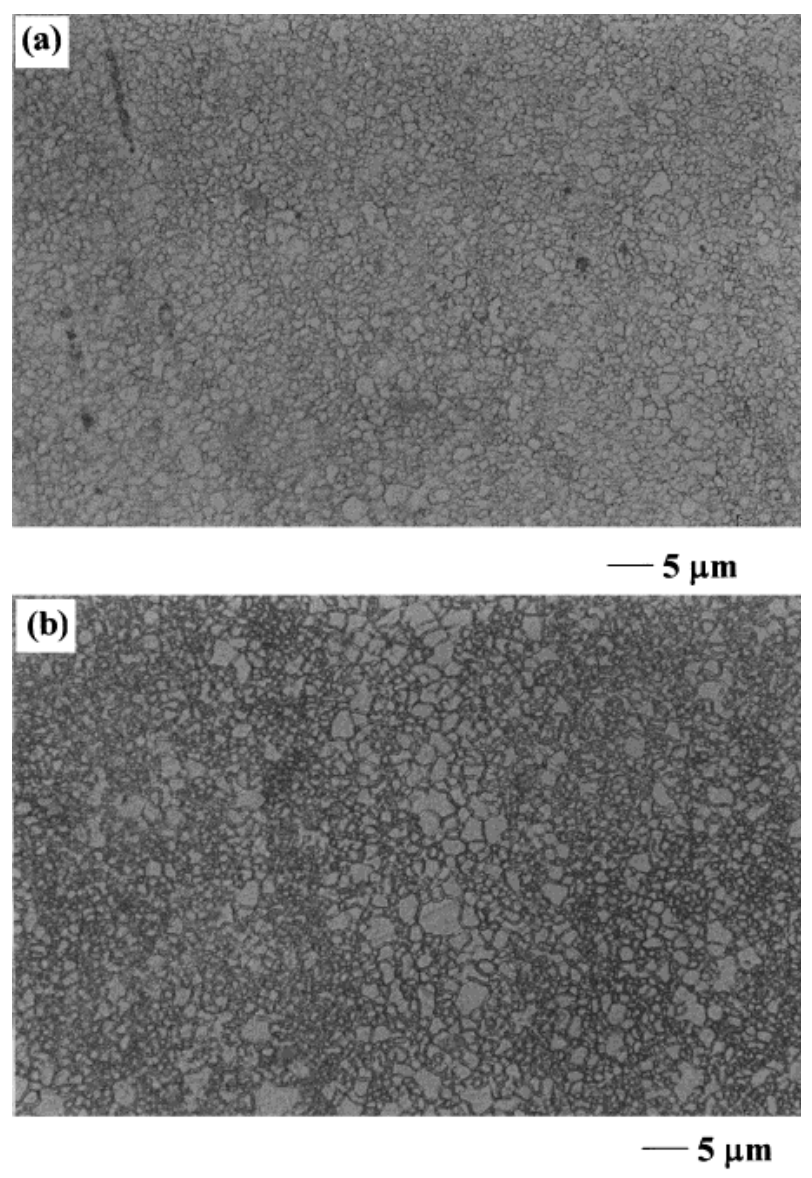

Fig. 1 Typical grain structures observed in the AZ31 Mg alloy under the (a) as-extruded condition, and (b) extruded and then statically annealed at $300^{\circ} \mathrm{C}$ for $1 \mathrm{~h}$.

at $200,250,280$, and $300^{\circ} \mathrm{C}$ (Table 2).

\subsection{Texture evolution}

The X-ray diffraction pattern computer simulated for complete random Mg powders is presented in Fig. 2(a). In comparison, Fig. 2(b) shows the experimental X-ray diffraction 

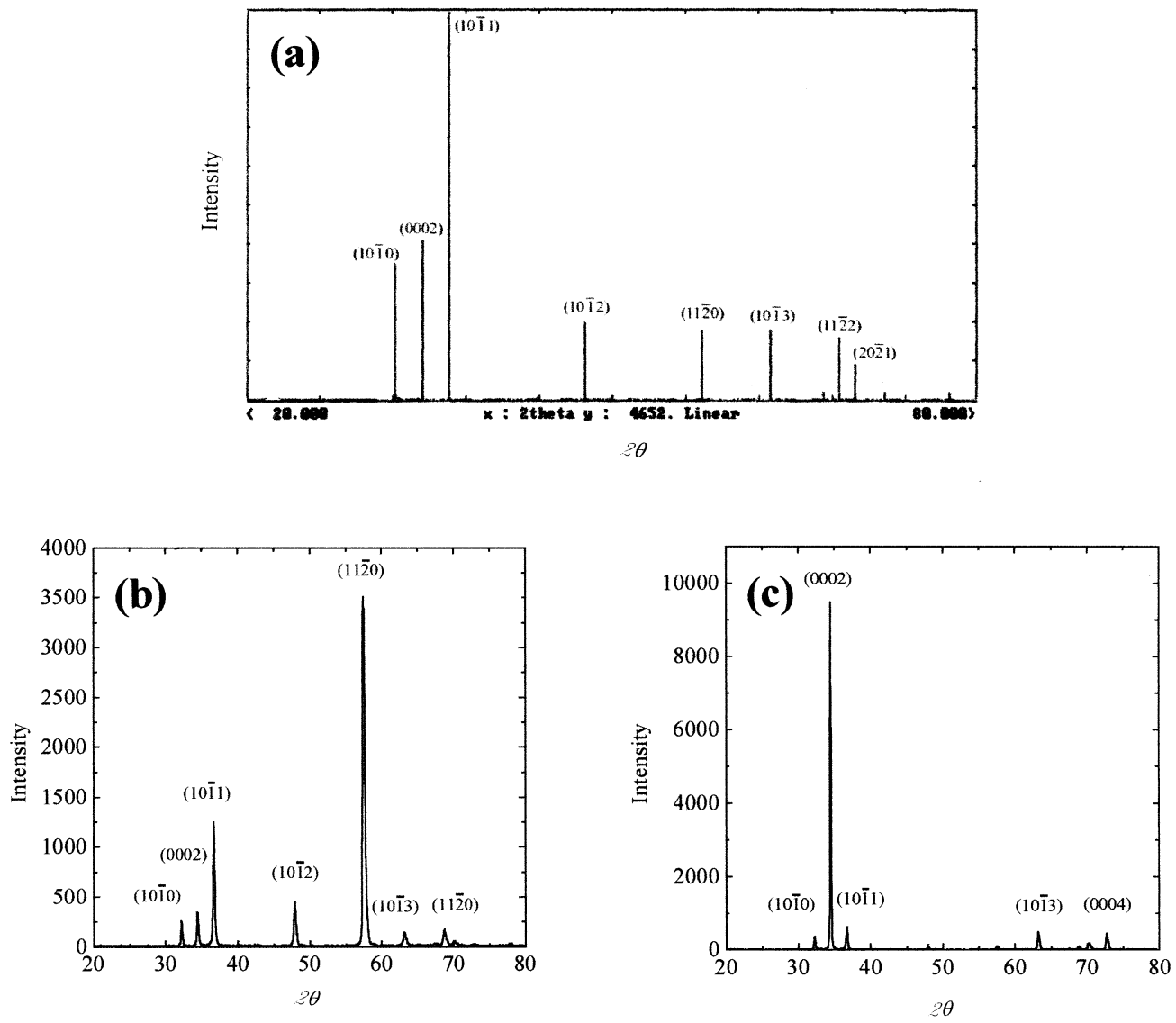

Fig. 2 X-ray diffraction patterns of the AZ31 Mg alloy showing the apparent change in texture after severe extrusion: (a) complete random $\mathrm{Mg}$ powders, (b) the as-received ingot processed by semi-continuous casting, and (c) the as-extruded plate. The intensity is referred to the X-ray count.

taken from the cross-sectional plane of the as-received billet. The $\{11 \overline{2} 0\}$ planes tended to lie on the cross-sectional plane. In other words, the $\{0002\}$ planes tended to lie on the plane that contains the extrusion axis. This has been typically observed in extruded or rolled Mg alloys. ${ }^{27)}$ The $\{10 \overline{1} 1\}$ peak, predicted to be the strongest X-ray peak for complete randomly-oriented samples, still ranked second in intensity, suggesting that the overall texture intensity was not significantly strong. In contrast, only one single strong and dominant texture was observed in the severely extruded plate, with predominantly $\{0002\}$ basal planes lying on the flat surface of the extruded plate, as seen in Fig. 2(c).

The strong $\{0002\}$ texture did not evolve much during static annealing at $150-300^{\circ} \mathrm{C}$ for $1-10 \mathrm{~h}$. However, appreciable evolution can be seen in specimens annealed at $350^{\circ} \mathrm{C}$, especially after $10 \mathrm{~h}$ annealing. Examples of the X-ray diffraction for the annealed specimens are shown in Fig. 3. The ratios of the peak intensity of the (0002) reflection and two other major peaks, (1011) and (1013), for the AZ31 alloy under various processing and annealing conditions are also listed in Table 2.

From Table 2, it can be seen that the strong $\{0002\}$ texture induced during severe extrusion was further enhanced by static annealing at $150-300^{\circ} \mathrm{C}$ for a short period of time for $1 \mathrm{~h}$. The peak ratio of $(0002) /(10 \overline{1} 1)$ increased from 14.6 for the as-extruded sample to 23 after annealing at $150^{\circ} \mathrm{C}$ for $1 \mathrm{~h}$; it was even further increased up to 60 for the sample annealed at $150^{\circ} \mathrm{C}$ for $10 \mathrm{~h}$. This suggests that recovery has occurred during the whole annealing treatment at $150^{\circ} \mathrm{C}$ and during the initial annealing stage at 250 and $300^{\circ} \mathrm{C}$. Partial recrystallization seemed to proceed at higher annealing temperatures and longer annealing time. Annealing at $250-300^{\circ} \mathrm{C}$ for $2-10 \mathrm{~h}$ seemed to involve initial recovery and subsequent partial recrystallization, resulting in the optimum grain size and mutual grain orientation. As described later, this condition happened to correspond to the regime for optimum low temperature and/or high strain rate superplasticity. At $350^{\circ} \mathrm{C}$, the ratios of $(0002) /(10 \overline{1} 1)$ and $(0002) /(10 \overline{1} 3)$ both decreased to $4-8$, meaning more recrystallized grains with orientations other than $\{0002\}$ have emerged and the overall grain size increased appreciably.

X-ray diffraction texture analysis has also been conducted by Mukai et $a .^{28)}$ on the AZ31 alloy processed by ECAP. It was reported that the $\{0002\}$ planes were not preferentially parallel to the extrusion direction, and the room temperature tensile ductility was greatly improved. In this study, the as-extruded or further annealed AZ31 specimens all contained strong $\{0002\}$ texture, and high tensile elongations at $25-300^{\circ} \mathrm{C}$ were similarly achieved (Sections 3.3 and 3.4). It seems that the fine grain size is the most critical factor in obtaining the superior tensile ductility. The strong initial texture was found to be substantially evolved and weakened into a more random manner during the tensile straining in $\mathrm{Al}$ base alloys. ${ }^{29)}$ Whether the similar situation would occur in the $\mathrm{Mg}$ base alloys will be examined in future study. 

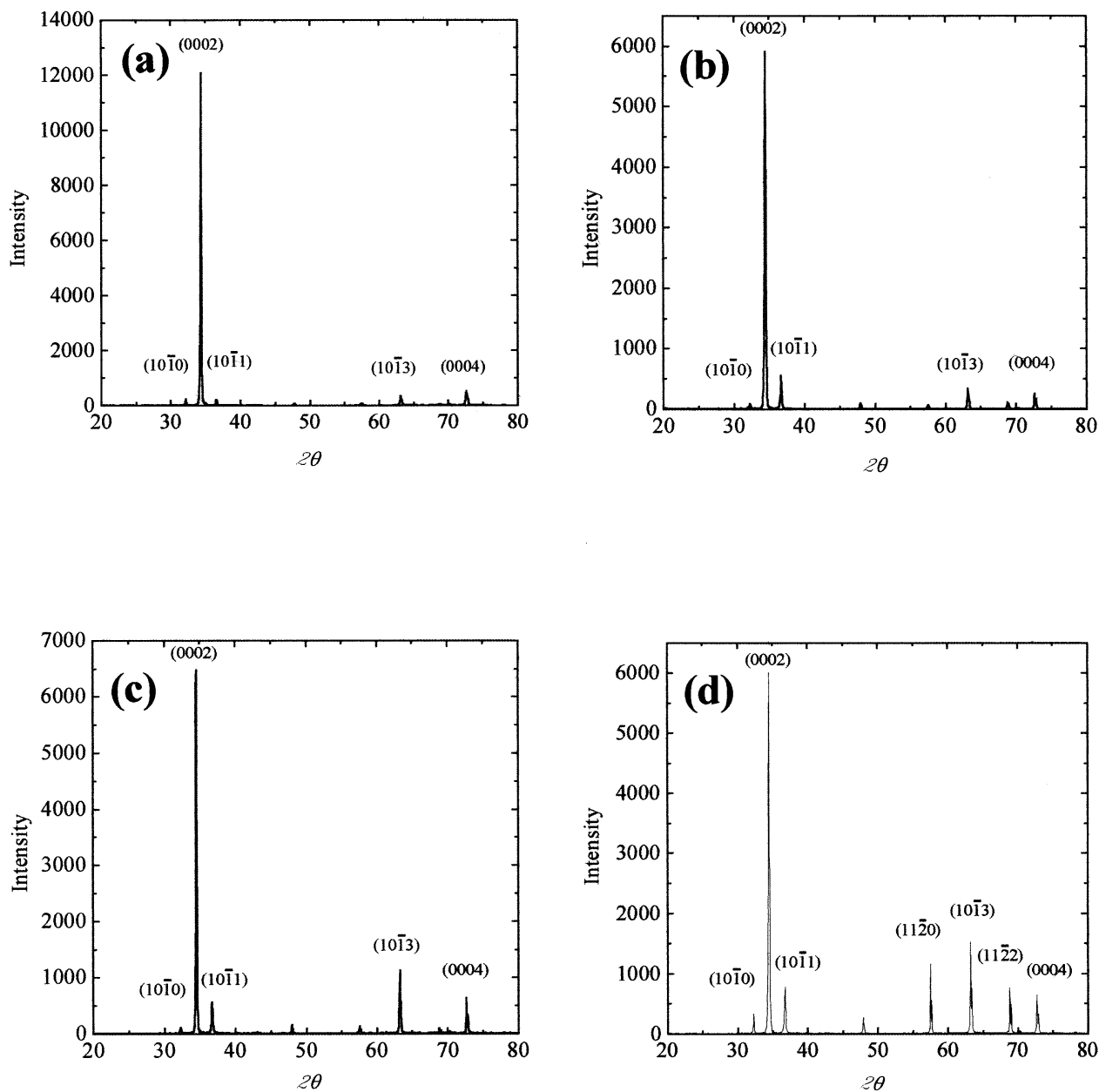

Fig. 3 X-ray diffraction patterns taken from the severely extruded $\mathrm{AZ} 31 \mathrm{Mg}$ alloy after further annealing for $10 \mathrm{~h}$ at (a) $150^{\circ} \mathrm{C}$, (b) $250^{\circ} \mathrm{C}$, and (c) $300^{\circ} \mathrm{C}$, and (d) $350^{\circ} \mathrm{C}$. The intensity is referred to the X-ray count.

\subsection{Room temperature tensile properties}

Figure 4 shows the typical engineering stress and strain curves for selected cases. The room temperature yield stress (YS), ultimate tensile stress (UTS) and elongation at $10^{-3} \mathrm{~s}^{-1}$ for the as-received AZ31 billet were $100 \mathrm{MPa}, 160 \mathrm{MPa}$, and $9 \%$, respectively, as listed in Table 3. After warm extrusion to $166: 1$, the data on the as-extruded specimen ( $2 \mathrm{~mm}$ thick) increased to $280 \mathrm{MPa}, 323 \mathrm{MPa}$ and $27 \%$, as compared in Table 3 . The as-extruded specimen showed low work hardening at room temperature. The high elongation of $27 \%$ for the as-extruded AZ31 specimens, much higher than the 10-15\% for commercial coarse-grained AZ31 alloys or similarly processed $5083 \mathrm{Al}$ alloys, was derived from the resulting uniform well-defined fine grain structures. Preliminary trials in extruding the AZ31 alloy (also to a high ratio of 166:1) into a thinner plate of $1.5 \mathrm{~mm}$ thick have resulted in better tensile elongation up to $50 \%$. Although extruded to the same ratio of 166:1, the thinner specimens appeared to possess a slightly finer and better defined grain structure. It seemed that the high room temperature tensile elongation was mainly originated from the grain refinement.

Upon static annealing at $150-300^{\circ} \mathrm{C}$ for $1-10 \mathrm{~h}$, the room temperature tensile strength and elongation for the $2 \mathrm{~mm}$ specimens did not change much, as evident from the data compared in Table 3. The maximum tensile elongation of $35 \%$ for the specimens $2 \mathrm{~mm}$ thick was obtained in speci-
Table 3 Room temperature tensile properties at $1 \times 10^{-3} \mathrm{~s}^{-1}$ for the AZ31 specimens after extrusion to $166: 1$ and post-annealing. All extruded and annealed specimens are $2 \mathrm{~mm}$ in thickness, except the one indicated.

\begin{tabular}{lccc}
\hline Material condition & YS (MPa) & UTS (MPa) & $e(\%)$ \\
\hline As-received ingot & 100 & 160 & 9 \\
As-extruded plate & 280 & 323 & 27 \\
As-extruded plate $(1.5 \mathrm{~mm}$ thick) & 275 & 310 & 50 \\
Post-annealed at $150^{\circ} \mathrm{C}$ for $1 \mathrm{~h}$ & 265 & 324 & 32 \\
Post-annealed at $150^{\circ} \mathrm{C}$ for $10 \mathrm{~h}$ & 280 & 323 & 28 \\
Post-annealed at $200^{\circ} \mathrm{C}$ for $1 \mathrm{~h}$ & 275 & 318 & 35 \\
Post-annealed at $200^{\circ} \mathrm{C}$ for $10 \mathrm{~h}$ & 280 & 317 & 32 \\
Post-annealed at $250^{\circ} \mathrm{C}$ for $1 \mathrm{~h}$ & 272 & 327 & 28 \\
Post-annealed at $250^{\circ} \mathrm{C}$ for $10 \mathrm{~h}$ & 276 & 316 & 29 \\
Post-annealed at $300^{\circ} \mathrm{C}$ for $1 \mathrm{~h}$ & 260 & 306 & 30 \\
Post-annealed at $300^{\circ} \mathrm{C}$ for $3 \mathrm{~h}$ & 255 & 302 & 31 \\
Post-annealed at $300^{\circ} \mathrm{C}$ for $5 \mathrm{~h}$ & 235 & 297 & 32 \\
Post-annealed at $300^{\circ} \mathrm{C}$ for $10 \mathrm{~h}$ & 232 & 290 & 33 \\
Post-annealed at $350^{\circ} \mathrm{C}$ for $1 \mathrm{~h}$ & 205 & 275 & 32 \\
Post-annealed at $350^{\circ} \mathrm{C}$ for $10 \mathrm{~h}$ & 190 & 268 & 21 \\
\hline
\end{tabular}

mens after static annealing at $200^{\circ} \mathrm{C}$ for $1 \mathrm{~h}$. In general, tensile elongations higher than $30 \%$ can be obtained by numerous annealing practices. The room temperature strength was not severely affected by annealing at $300^{\circ} \mathrm{C}$ or below, a result consistent with the measured grain size and texture evolution. 


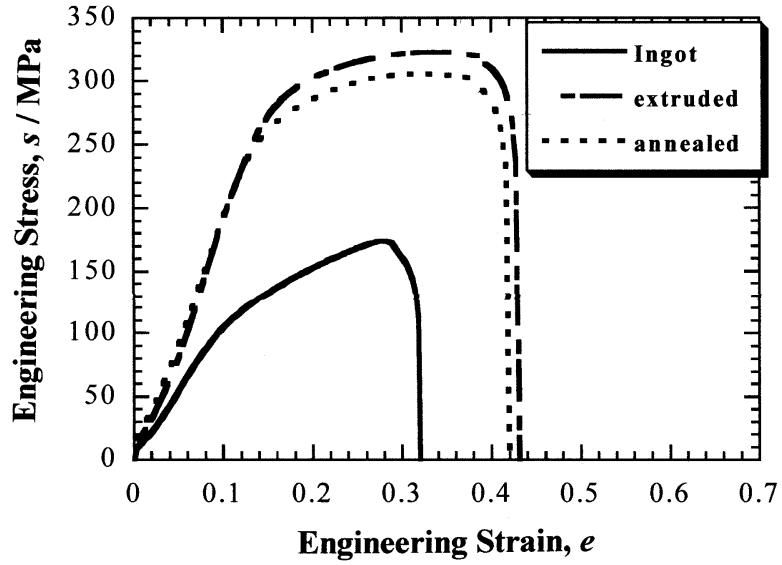

Fig. 4 Typical room temperature stress and strain curves for the AZ31 $\mathrm{Mg}$ alloy under the as-received, as-extruded, and extruded + annealed (at $300^{\circ} \mathrm{C}$ for $1 \mathrm{~h}$ ) conditions.

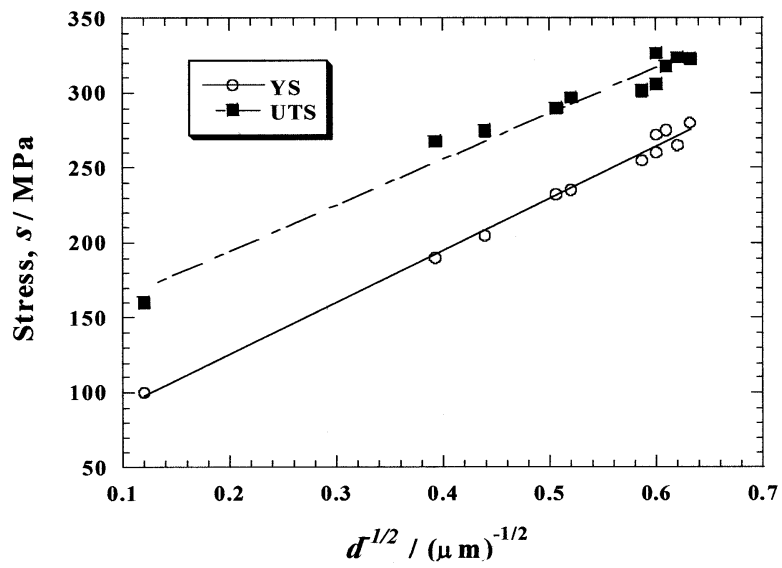

Fig. 5 Variation of the yield and ultimate tensile stresses of the AZ31 Mg alloy as a function of $d^{-1 / 2}$ in accordance with the Hall-Petch relationship.

Annealing at $350^{\circ} \mathrm{C}$ for $10 \mathrm{~h}$ will however reduce the UTS strength and elongation to $268 \mathrm{MPa}$ and $21 \%$, a level closer to commercial coarse-grained AZ31 alloys.

The room temperature YS and UTS data were seen to follow Hall-Petch relationship, as shown in Fig. 5. Using the unit of MPa for the YS and UTS data and $\mu \mathrm{m}$ for the grain size $d$, the relationship can be expressed by

$$
\sigma_{\mathrm{YS}}=56+348 d^{-1 / 2},
$$

and

$$
\sigma_{\mathrm{UTS}}=133+307 d^{-1 / 2} .
$$

The K-slope of these equations might be somewhat higher than the value reported in literature, ${ }^{30)}$ usually less than $250 \mathrm{MPa} \cdot \mu \mathrm{m}^{1 / 2}$. This might be due to the fact that those stress data corresponding to small grain sizes included some work hardening contribution, thus raising the K-slope. Recent research by Mabuchi et al. ${ }^{31)}$ also suggested the importance of microscopic orientation effect on the K-value. It should be noted that the $\mathrm{K}$-slope for $\mathrm{Mg}$ base alloys is much higher than that for Al base alloys $\left(\sim 60 \mathrm{MPa} \cdot \mu \mathrm{m}^{1 / 2}\right),{ }^{32)}$ so that the benefit gained from grain refinement in $\mathrm{Mg}$ alloys will also be much higher.
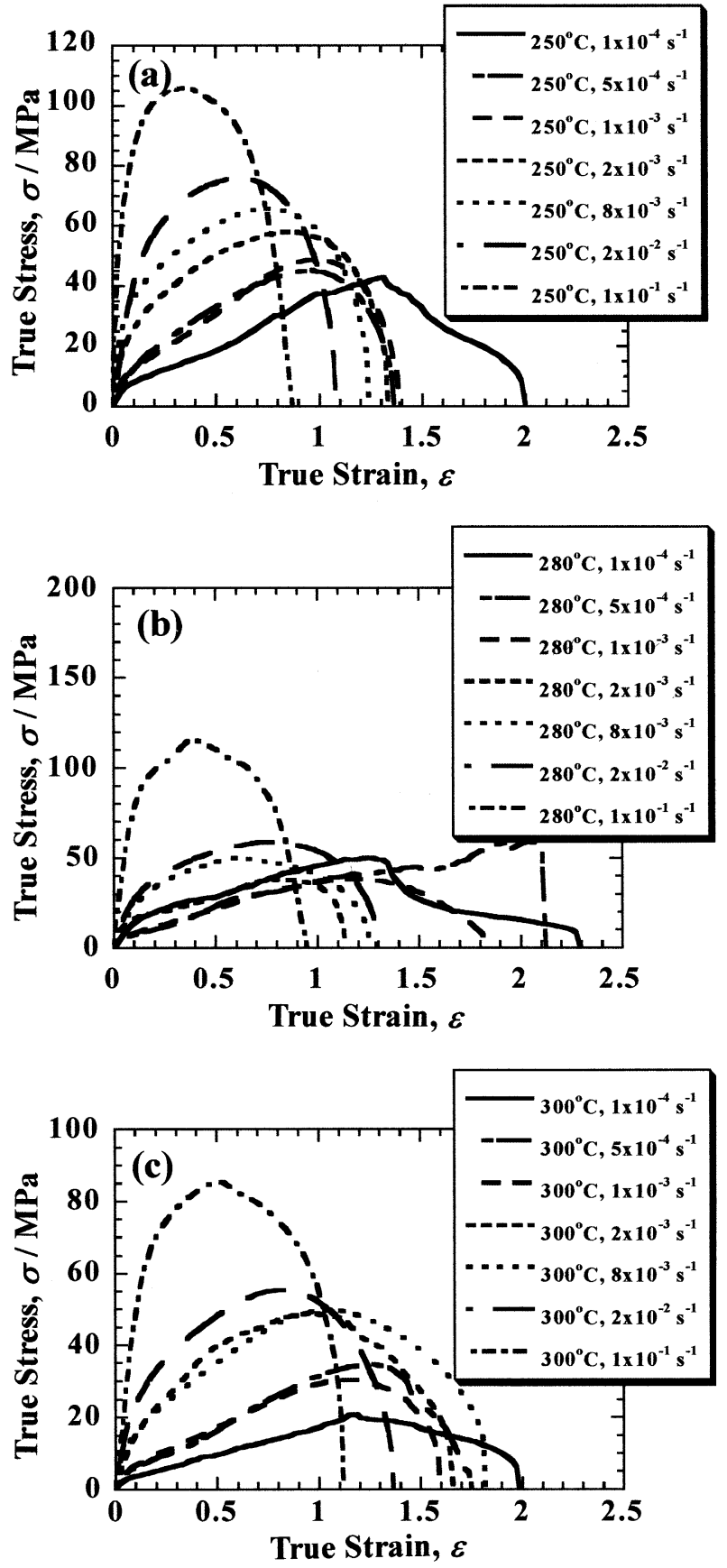

Fig. 6 Typical stress and strain curves for the AZ31 Mg alloy tensile loaded at (a) $250^{\circ} \mathrm{C}$, (b) $280^{\circ} \mathrm{C}$, and (c) $300^{\circ} \mathrm{C}$.

\subsection{Superplastic behavior over $200-350^{\circ} \mathrm{C}$ and $10^{-4}$ $10^{-1} \mathrm{~s}^{-1}$}

Figure 6 shows the typical true stress and strain curves for the extruded AZ31 at various temperatures and strain rates. Only the curves for 250,280 and $300^{\circ} \mathrm{C}$ are shown, since higher superplastic elongations were observed at these temperatures. When the specimens exhibited large elongations, the alloy tended to be strain-hardened first until $\varepsilon \sim 1.0$, followed by rapid softening.

Over the test temperature range of $25-350^{\circ} \mathrm{C}$ examined, the extruded AZ31 alloy exhibited high strain rate and/or low temperature superplasticity at $200-300^{\circ} \mathrm{C}$. The variation of superplastic elongation as a function of strain rate at $250-300^{\circ} \mathrm{C}$ is depicted in Fig. 7. The maximum LTSP elon- 


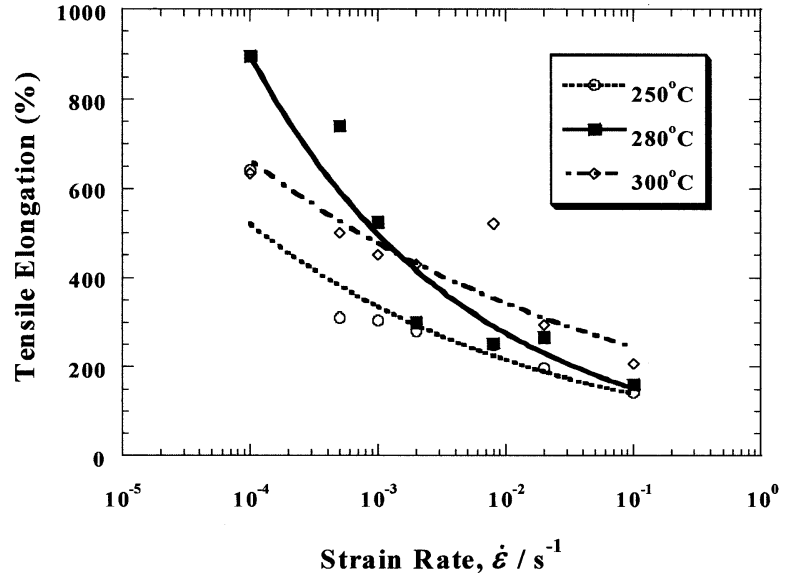

Fig. 7 Variation of the tensile elongation as a function of test strain rate for the AZ31 Mg alloy.

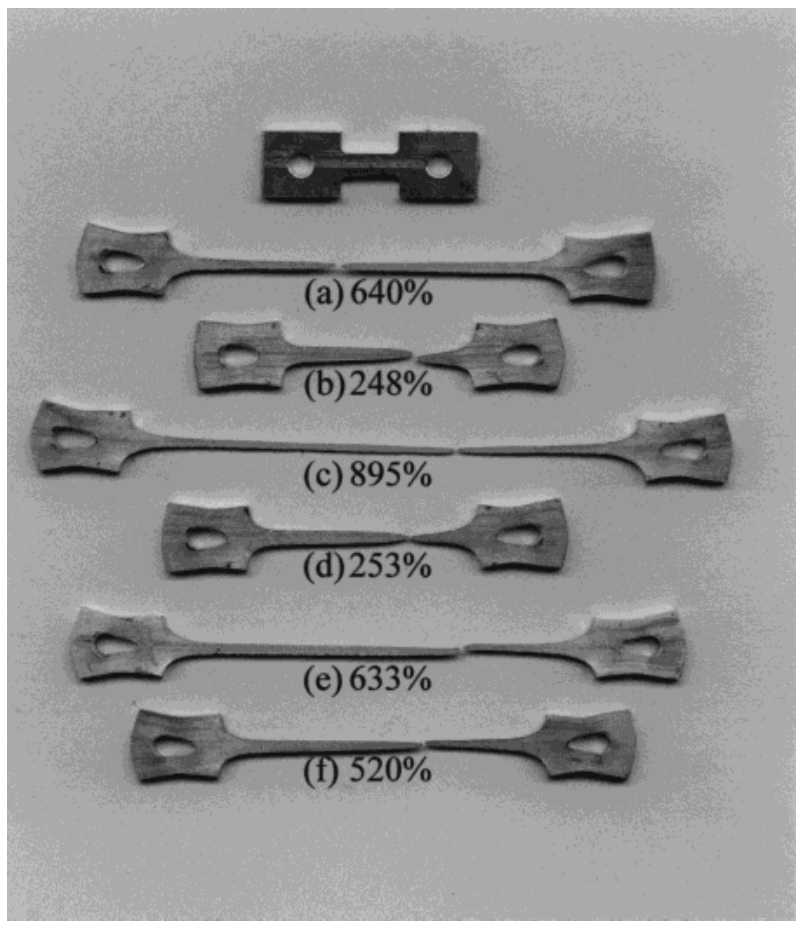

Fig. 8 Representative tensile specimens of the AZ31 Mg alloy: (a) $250^{\circ} \mathrm{C}$ and $1 \times 10^{-4} \mathrm{~s}^{-1}$, (b) $250^{\circ} \mathrm{C}$ and $8 \times 10^{-3} \mathrm{~s}^{-1}$, (b) $280^{\circ} \mathrm{C}$ and $1 \times 10^{-4} \mathrm{~s}^{-1}$, (b) $280^{\circ} \mathrm{C}$ and $8 \times 10^{-3} \mathrm{~s}^{-1}$, (b) $300^{\circ} \mathrm{C}$ and $1 \times 10^{-4} \mathrm{~s}^{-1}$, (b) $300^{\circ} \mathrm{C}$ and $8 \times 10^{-3} \mathrm{~s}^{-1}$.

gation of $900 \%$ occurred at $280^{\circ} \mathrm{C}$ and $1 \times 10^{-4} \mathrm{~s}^{-1}$; the tested specimens are shown in Fig. 8. An elongation of $520 \%$ can also be achieved at $300^{\circ} \mathrm{C}$ and $8 \times 10^{-3} \mathrm{~s}^{-1}$. At $300^{\circ} \mathrm{C}$ and higher strain rates of $2 \times 10^{-2}$ and $1 \times 10^{-1} \mathrm{~s}^{-1}$, the elongation still maintained at $300 \%$ and $210 \%$, suggesting that the current processed AZ31 $\mathrm{Mg}$ alloy has possessed HSRSP at relatively low temperatures of $280-300^{\circ} \mathrm{C}$, which corresponds to around $0.6 T_{\mathrm{m}}$ where $T_{\mathrm{m}}$ is the melting point expressed in Kelvin. At a lower temperature of $200^{\circ} \mathrm{C}\left(\sim 0.5 T_{\mathrm{m}}\right)$, the tensile elongations were $600 \%$ at $1 \times 10^{-4} \mathrm{~s}^{-1}, 425 \%$ at $1 \times 10^{-3} \mathrm{~s}^{-1}, 150 \%$ at $1 \times 10^{-2} \mathrm{~s}^{-1}$, and $125 \%$ at $1 \times 10^{-1} \mathrm{~s}^{-1}$, suggesting that the alloy exhibited LTSP as well. At temperatures $T<200^{\circ} \mathrm{C}\left(\right.$ e.g., 75,100 , and $\left.150^{\circ} \mathrm{C}\right)$ and $T>300^{\circ} \mathrm{C}$ (e.g. $350^{\circ} \mathrm{C}$ ), the elongations tended to be degraded to below $300 \%$ at all strain rates examined. Figure 9 shows the ten-

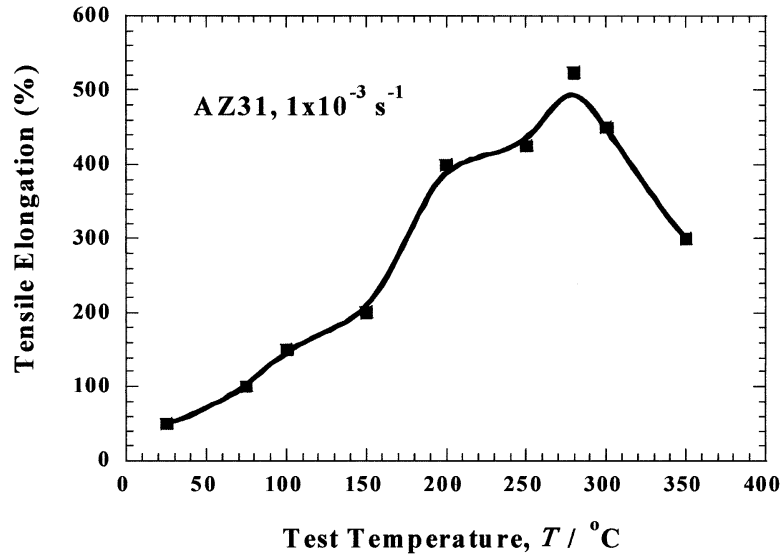

Fig. 9 Variation of the tensile elongation as a function of test temperature for the AZ31 Mg alloy.

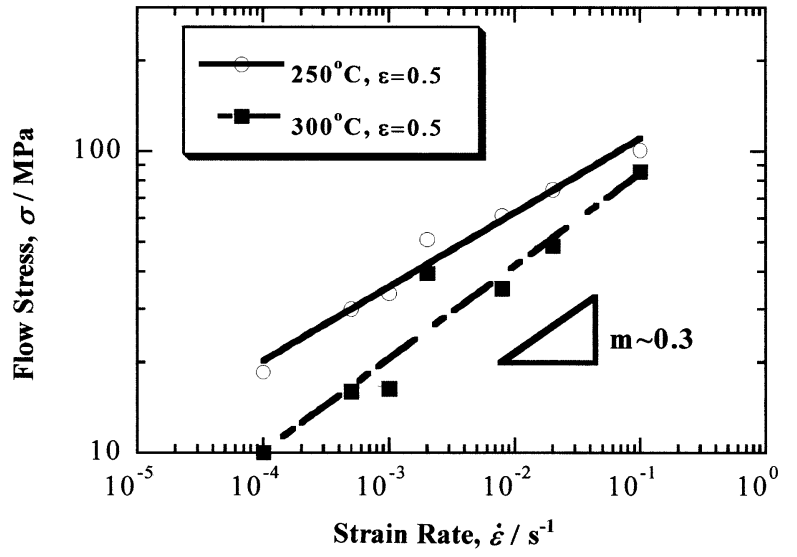

Fig. 10 Variation of true stress at $\varepsilon=0.5$ as a function of strain rate for the AZ31 Mg alloy.

sile elongations at a reasonable strain rate of $1 \times 10^{-3} \mathrm{~s}^{-1}$; the elongation increased from 30-50\% at room temperature to $\sim 100 \%$ at $75^{\circ} \mathrm{C}, \sim 150 \%$ at $100^{\circ} \mathrm{C}, \sim 200 \%$ at $150^{\circ} \mathrm{C}$, $\sim 400 \%$ at $200^{\circ} \mathrm{C}$, and above $500 \%$ at $280^{\circ} \mathrm{C}$. To achieve a minimum tensile elongation of $\sim 100 \%$ for forming a cellphone enclosure, the alloy needs to be heated (for example in boiled water or oil bath) to $\sim 75^{\circ} \mathrm{C}$ for press forming or press forging. Although press formability requires many other material properties such as strength, strain hardening, anisotropy factor, etc., the current results imply that the simple high-ratio extrusion method might be a feasible processing mean for industry applications.

Figure 10 shows the stress at $\varepsilon \sim 0.5$ versus strain rate at two temperatures. Under the optimum superplastic working range at $10^{-3}-10^{-2} \mathrm{~s}^{-1}$ and $280-300^{\circ} \mathrm{C}$, the flow stresses were scattered within $15-30 \mathrm{MPa}$, and the apparent strain rate sensitivity $\mathrm{m}$-values were around 0.3 . With the consideration of threshold stress, especially important for LTSP data, ${ }^{33,34)}$ the true strain rate sensitivity was around 0.4 , suggesting that grain boundary sliding and solute drag creep might have both contributed to the overall deformation mechanisms. Detailed analyses on the deformation mechanism in HSRSP and/or LTSP Mg alloys will be presented elsewhere. 
Table 4 Comparison of the AZ31B and AZ91D Mg alloys processed by high-ratio (HR) extrusion and ECAP.

\begin{tabular}{|c|c|c|c|c|}
\hline Item & $\begin{array}{c}\text { AZ31B } \\
\text { HR extrusion }\end{array}$ & $\begin{array}{l}\text { AZ31B } \\
\text { ECAP }^{28)}\end{array}$ & $\begin{array}{c}\text { AZ91D } \\
\text { HR extrusion }\end{array}$ & $\begin{array}{c}\text { AZ91D } \\
\text { ECAP }^{6,7)}\end{array}$ \\
\hline Strain during processing & 5.1 & 8.1 & 5.1 & 8.1 \\
\hline Grain size & $2.5 \mu \mathrm{m}$ & $1 \mu \mathrm{m}$ & $2 \mu \mathrm{m}$ & $1 \mu \mathrm{m}$ \\
\hline Room temp. UTS & $320 \mathrm{MPa}$ & $270 \mathrm{MPa}$ & $350 \mathrm{MPa}$ & - \\
\hline Max room temp. elongation & $50 \%$ & $50 \%$ & $18 \%$ & - \\
\hline
\end{tabular}

\subsection{Comparison with specimens processed by ECAP}

Another processing method used in reducing the grain size and improving the LTSP or HSRSP performance is the ECAP process. With the significant success achieved on the $\mathrm{Al}$ base alloys, e.g. ${ }^{35)}$ there have been however very limited reports on the advances in Mg base alloys. ${ }^{6,7,28)}$ The first report might be the result on the AZ91 Mg alloy by Mabuchi et al. in 1997.6) The grain size after 8 passes of ECAP $(\varepsilon=8.05)$ at $175^{\circ} \mathrm{C}$ was $1 \mu \mathrm{m}$ and a LTSP elongation of $661 \%$ was obtained at $200^{\circ} \mathrm{C}$ and $6 \times 10^{-5} \mathrm{~s}^{-1}$. Similar ECAP work was performed on the $\mathrm{AZ} 31 \mathrm{Mg}$ alloy at $200^{\circ} \mathrm{C}$, also resulting in fine grain size around $1 \mu \mathrm{m} .{ }^{28)}$ The ECAP AZ31 specimens were further annealed at $300^{\circ} \mathrm{C}$ for $24 \mathrm{~h}$ in order to form well-defined equiaxed grains with the desired grain orientation; ${ }^{28)}$ and the room temperature tensile elongation reached an outstanding level of $\sim 50 \%$. In addition, recent ECAP work on pure $\mathrm{Mg}$ and dilute $\mathrm{Mg}-\mathrm{Al}$ binary alloy ${ }^{36)}$ also showed appreciable improvement of the room temperature mechanical properties.

Table 4 compares the previous ECAP work $^{6,7,28)}$ with the current high-ratio extrusion processing. The true strain experienced by the one-step high-ratio extrusion $(\varepsilon \sim 5)$ was slightly lower than that during multiple-pass ECAP $(\varepsilon \sim$ 6-8). Also, the working temperature for high-ratio extrusion $\left(250-350^{\circ} \mathrm{C}\right)$ was higher than that for ECAP $\left(\sim 200^{\circ} \mathrm{C}\right)$. The slight differences in processing strain and working temperature were also reflected by the slightly larger grain size observed in the as-extruded specimens than that in the ECAP ones. However, the current optimum LTSP results based on the high-ratio extrusion experiment appeared to be compatible to those fabricated by ECAP, both above $600 \%$ at low temperatures and low strain rates. The room temperature tensile elongation in specimens processed by high-ratio extrusion or ECAP followed by low-temperature annealing both increased to $35-50 \%$, much higher than commercial large-grained $\mathrm{Mg}$ alloys (mostly $<15 \%$ ). It should be noted that the high room temperature elongation of 50\% obtained in AZ31 specimens subjected to ECAP plus full annealing was due to texture control (with relatively more random texture and a larger grain size of $\sim 20 \mu \mathrm{m}$ ), ${ }^{28)}$ but the current case was mainly due to grain refinement (with strong basal texture and a fine grain size of $\sim 2.5 \mu \mathrm{m}$ ). In any case, it appears that thermomechanical processing using severe plastic deformation means of either high-ratio extrusion or ECAP will be effective in improving the mechanical properties.

\subsection{Comparison between extruded AZ31 and AZ91 alloys}

Table 4 also includes the comparison between the AZ31 and AZ91 Mg alloys processed by the same high-ratio extrusion method. With the higher $\mathrm{Al}$ content, and thus with the presence of $\beta\left(\mathrm{Mg}_{17} \mathrm{Al}_{12}\right)$ precipitates, the $\mathrm{AZ91}$ alloy exhibited a higher room temperature tensile strength but lower elongation than the AZ31 counterpart. Meanwhile, the presence of fine $\beta$ precipitates seemed to be highly effective in controlling the grain size during superplasticity loading at $\sim 300^{\circ} \mathrm{C}$. This effect resulted in the superior superplsticity elongation of $1200 \%$ at $300^{\circ} \mathrm{C}$ and $1 \times 10^{-3} \mathrm{~s}^{-1}$ observed in the high-ratio extruded AZ91 alloy, ${ }^{14)}$ an elongation which is higher than the $900 \%$ at $280^{\circ} \mathrm{C}$ and $1 \times 10^{-4} \mathrm{~s}^{-1}$ obtained from the high-ratio extruded AZ31 alloy. Parallel work on the AZ91 alloys also showed that the one-step extrusion could be replaced by two-step extrusion with the same total accumulated strain. ${ }^{14)}$

\section{Conclusions}

There have been numerous efforts in processing metallic alloys into fine-grained materials, so as to exhibit high strain rate superplasticity (HSRSP) and/or low temperature superplasticity (LTSP). The current study applied the most simple and feasible one-step extrusion method on the commercial AZ31 magnesium billet to result in HSRSP and/or LTSP. The one-step extrusion was undertaken using a high extrusion ratio at $250-350^{\circ} \mathrm{C}$, and the grain size after one-step extrusion became $\sim 1-4 \mu \mathrm{m}$. The processed AZ31 plate exhibited high room temperature tensile elongation of 30-50\%; $200^{\circ} \mathrm{C}$ elongations of $600 \%$ at $1 \times 10^{-4} \mathrm{~s}^{-1}$ and $425 \%$ at $1 \times 10^{-3} \mathrm{~s}^{-1} ; 300^{\circ} \mathrm{C}$ elongations of $\sim 900 \%$ at $1 \times 10^{-4} \mathrm{~s}^{-1}$, $520 \%$ at $8 \times 10^{-3} \mathrm{~s}^{-1}, 300 \%$ at $2 \times 10^{-2} \mathrm{~s}^{-1}$, and $210 \%$ at $1 \times 10^{-1} \mathrm{~s}^{-1}$ at relatively low temperatures of $280-300^{\circ} \mathrm{C}$. This suggests that the current AZ31 Mg alloy has possessed HSRSP at relatively low temperatures of $280-300^{\circ} \mathrm{C}$, as well as LTSP at $200^{\circ} \mathrm{C}$. The low flow stress of $\sim 15-30 \mathrm{MPa}$ and the true strain rate sensitivity of $\sim 0.3-0.4$ both suggest that grain boundary sliding and solute drag creep have operated under these loading conditions. Meanwhile, the extruded alloys tensile loaded at $1 \times 10^{-3} \mathrm{~s}^{-1}$ revealed elongations of $\sim 100 \%$ at $75^{\circ} \mathrm{C}, \sim 150 \%$ at $100^{\circ} \mathrm{C}, \sim 200 \%$ at $150^{\circ} \mathrm{C}, \sim 400 \%$ at $200^{\circ} \mathrm{C}$, and above $500 \%$ at $280^{\circ} \mathrm{C}$. To achieve a minimum tensile elongation of $\sim 100 \%$ for forming a cell-phone enclosure, the current severely extruded AZ31 plates or sheets need to be heated (for example in boiled water or oil bath) to $\sim 75^{\circ} \mathrm{C}$ for press forming or press forging. 
The present results imply that the simple high-ratio extrusion method might be a feasible processing mean for industry applications.

\section{Acknowledgements}

The authors would like to acknowledge the sponsorship from National Science Council of Taiwan, ROC, under the project no. NSC-90-2216-E-110-024.

\section{REFERENCES}

1) H. Watanabe, T. Mukai, K. Ishikawa, Y. Okanda and K. Higashi: J. Jpn. Inst. Light Metals 49 (1999) 401-406.

2) A. Bussiba, A. B. Artzy, A. Shtechman, S. Ifergan and M. Kupiec: Mater. Sci. Eng. A302 (2001) 56-62.

3) H. Watanabe, H. Tsutsui, T. Mukai, K. Ishikawa, Y. Okanda, M. Kohzu and K. Higashi: Mater. Sci. Forum 350-351 (2000) 171-176.

4) J. K. Solberg, J. Torklep, O. Bauger and H. Gjestland: Mater. Sci. Eng. A134 (1991) 1201-1203.

5) M. Mabuchi, T. Asahina, H. Iwasaki and K. Higashi: Mater. Sci.Tech. 13 (1997) 825-831.

6) M. Mabuchi, H. Iwasaki, K. Yanase and K. Higashi: Scr. Mater. 36 (1997) 681-686.

7) M. Mabuchi, M. Nakamura, K. Ameyama, H. Iwasaki and K. Higashi: Mater. Sci. Forum 304-306 (1999) 67-72.

8) M. Mabuchi, K. Kubota and K. Higashi: Mater. Trans., JIM 36 (1995) 1249-1254.

9) J. Kaneko, M. Sugamata and N. Hisata: Mater. Sci. Forum 304-306 (1999) 85-90.

10) H. Watanabe, T. Mukai and K. Higashi: Scr. Mater. 40 (1999) 477-484.

11) H. Watanabe, T. Mukai and K. Higashi: Mater. Sci. Forum 304-306 (1999) 303-308.

12) H. Watanabe, T. Mukai, M. Mabuchi and K. Higashi: Scr. Mater. 41 (1999) 209-213.

13) R. G. Chang (under the guidance of J. W. Yeh): Master Thesis, Tsing Hua University, 2000.

14) H. K. Lin and J. C. Huang: Key Engineering Materials, in press (2002).

15) R. Kariya, H. Iwasaki, T. Mori, T. Mohri, M. Mabuchi, M. Nakamura,
T. Asahina and K. Higashi: Mater. Sci. Forum 305-351 (2000) 93-96. 16) H. Somekawa, M. Kohzu, S. Tanabe and K. Higashi: Mater. Sci. Forum 350-351 (2000) 177-182.

17) H. J. Frost and M. F. Ashby: Deformation-Mechanism Maps, (Pergamon Press, Oxford, 1982) p. 21 and p. 44.

18) H. Iwasaki, K. Yanase, T. Mori, M. Mabuchi and K. Higashi: J. Japan Soc. Powder Metall. 43 (1996) 1350-1355.

19) M. Mabuchi, T. Asahina, H. Iwasaki and K. Higashi: Mater. Sci. Tech. 13 (1997) 825-831.

20) H. Watanabe, T. Mukai, K. Ishikawa and K. Higashi: Mater. Trans. 43 (2002) 78-80.

21) R. S. Mishra, T. R. Bieler and A. K. Mukherjee: Acta Metall. Mater. 43 (1995) 877-891.

22) M. Mabuchi, K. Kubota and K. Higashi: Scr. Metall. Mater. 33 (1995) 331-335.

23) T. G. Nieh, A. J. Schwartz and J. Wadsworth: Mater. Sci. Eng. A208 (1996) 30-36.

24) X. Wu, Y. Liu and H. Hao: Mater. Sci. Forum 357-359 (2001) 363-370.

25) X. Wu and Y. Liu: Scr. Mater. 46 (2002) 269-274.

26) T. Mukai, H. Watanabe and K. Higashi: Mater. Sci. Forum 350-351 (2000) 159-170.

27) M. T. Perez-Prado and O. A. Ruano: Scr. Mater. 46 (2002) 149-155.

28) T. Mukai, M. Yamanoi, H. Watanabe and K. Higashi: Scr. Mater. 45 (2001) 89-94.

29) I. C. Hsiao, S. W. Su and J. C. Huang: Metall. Mater. Trans. 31A (2000) 2169-2180.

30) G. Nussbaum, P. Sainfort, G. Regazzoni and H. Gjestland: Scr. Metall. 23 (1989) 1079-1084.

31) M. Mubuchi, Y. Chino, H. Iwasaki, T. Aizawa and K. Higashi: Mater. Trans. 42 (2001) 1182-1189.

32) T. Mukai, K. Ishikawa and K. Higashi: Mater. Sci. Eng. A204 (1995) 12-18.

33) H.-P. Pu, F. C. Liu and J. C. Huang: Metall. Mater. Trans. 26A (1995) 1153-1166.

34) I. C. Hsiao and J. C. Huang: Metall. Mater. Trans. 33A (2002) 13731384.

35) R. Z. Valiev, D. A. Salimonenko, N. K. Tsenev, P. B. Berbon and T. G. Langdon: Scr. Mater. 37 (1997) 1945-1950.

36) A. Yamashita, Z. Horita, Z. Horita and T. G. Langdon: Mater. Sci. Eng. A300 (2001) 142-147. 